\title{
PENGARUH SUMBER DAN LAMA SIMPAN BATANG ATAS TERHADAP PERTUMBUHAN HASIL GRAFTING TANAMAN DURIAN
}

\section{EFFECT OF SOURCES AND STORAGE PERIODE ON THE GROWTH OF UPPER STEM OF DURIAN GRAFTING PLANT}

\author{
Suharjo Thalib \\ Fakultas Pertanian Universitas Lakidende Unaaha, Indonesia \\ Jln Sultan Hasanuddin 234 Unaaha Kabupaten Konawe Sulawesi Tenggara \\ Korespondensi: suharjo.unilaki@gmail.com
}

Diterima: 28 Oktober 2019 / Disetujui: 27 Desember 2019

\begin{abstract}
ABSTRAK
Pertumbuhan bibit setelah penyambungan dipengaruhi oleh sumber batang atas yang digunakan. Selama ini penggunaan batang atas sebagai bahan grafting masih besifat umum yaitu penggunaan sumber batang atas belum spesifik berasal dari cabang tertentu sehingga belum jelas sumber batang atas yang dapat meningkatkan keberhasilan sambungan. Penelitian ini ingin mengkaji keberhasilan penyambungan dengan menggunakan entres dari berbagai cabang dan lama penyimpanannya. Penelitian dilaksanakan menggunakan Rancangan Acak Kelompok pola faktorial dengan tiga ulangan. Faktor pertama menggunakan berbagai jenis sumber cabang (primer, sekunder, tersier). Perlakuan kedua yaitu lamanya waktu penyimpanan cabang ( 0 hari, 2 hari, 4 hari, 6 hari). Hasil Penelitian menunjukkan bahwa interaksi sumber dan lama penyimpanan batang atas tidak mempengaruhi jumlah tunas, panjang tunas, diameter tunas dan luas daun total tanaman durian hasil grafting. Sumber batang hanya mempengaruhi diameter batang saja.
\end{abstract}

Kata kunci: Sumber batang atas, lama penyimpanan, tanaman durian

\begin{abstract}
Seedling growth after grafting is effected by the source of the upper stem. Currently, the stem used as grafting material is not in particular source and part of the branch, so it is unclear to determine the success of this activity. This study wanted to examine the success of the interaction between entres upper stem from various branches and the duration of storage. The study used factorial randomized block design with two factors and three replications. The first factor was various types of branch sources (primary branch, secondary branch, tertiary branch). The second factor was the storage time periode ( 0 day, 2 days, 4 days, 6 days). The results showed that the interaction of the branch source and duration of storage of the upper
\end{abstract}

Cite this as: Thalib, S. (2019). Pengaruh sumber dan lama simpan batang atas terhapa pertumbuhan hasil grafting tanaman durian. Jurnal Agro, 6(2), 196-205 https://doi.org/10.15575/6254 
stem did not affect the number of shoots, shoot length, shoot diameter and total leaf area of durian grafting plants. The source of the stem only affected the diameter of the stem.

Cite this as: Thalib, S. (2019). Pengaruh sumber dan lama simpan batang atas terhapa pertumbuhan hasil grafting tanaman durian. Jurnal Agro, 6(2), 196-205 https://doi.org/10.15575/6254 
Keywords: Upper stem source, storage duration, durian plant

\section{PENDAHULUAN}

Salah satu faktor penting dalam pengelolaan budidaya tanaman buahbuahan adalah penggunaan bibit bermutu baik, terutama dari hasil pembiakan vegetatif (Adelina et al., 2009). Bibit unggul merupakan syarat utama untuk menunjang pertumbuhan tanaman durian. Bibit unggul dapat diperoleh dengan cara perbanyakan secara vegetatif. Pada tanaman buahbuahan, perbanyakan vegetatif adalah cara yang tepat untuk memperoleh bibit bermutu, khususnya sambung pucuk (grafting). Grafting adalah teknik menyatukan pucuk yang berfungsi sebagai calon batang atas dengan calon batang bawah, sehingga dapat diperoleh batang baru yang memiliki sifat-sifat unggul. Keunggulan dari grafting yaitu lebih mudah dan lebih cepat dalam pengerjaannya (sederhana), serta tingkat keberhasilannya cukup tinggi (Vural et al., 2009). Keberhasilan grafting sangat ditentukan oleh batang bawah untuk disambung serta kompatibilitas antara batang atas dan batang bawah (Yang et al., 2015). Disamping itu keberhasilan penyambungan ditandai dengan terbentuknya pertautan yang sempurna antara batang bawah dan batang atas serta laju pertumbuhan bibit hasil sambungan (Ciobotari et al., 2010; Suharjo et al., 2017).

Teknologi perbanyakan yang disarankan dalam budidaya durian waktu cepat adalah mini grafting (sambung mini), yaitu teknik perbanyakan vegetatif yang dilakukan seawal mungkin pada kondisi batang bawah yang telah memungkinkan untuk disambung. Salah satu faktor yang sangat mempengaruhi keberhasilan dengan metode grafting adalah kesegaran batang atas (Adelina et al., 2009; Syah et al., 2009). Kesegaran batang atas berkaitan dengan kecukupan cadangan makanan/ energi berupa kandungan asimilat untuk pertumbuhan dan pemulihan sel-sel yang rusak akibat pelukaan, makin segar batang atas maka makin banyak pula cadangan energinya. Penggunaan dan pemilihan tipe batang atas yang baik dan mengetahui kapan batang bawah berada dalam stadia aktivitas vegetatif yang baik merupakan pertimbangan penting berhasilnya penyatuan sambungan, sehingga perlu diketahui sumber batang atas yang paling sesuai untuk disambung pada masingmasing varietas. Pertumbuhan bibit setelah penyambungan (tinggi batang atas dan lebar daun bibit) dipengaruhi oleh sumber batang atas yang digunakan. Asimilat dapat merangsang pembelahan, pembesaran dan deferensiasi sel, yang kemudian mendorong proses pertautan antara batang atas dan bawah (Firman dan Ruskandi, 2009; Sudjijo, 2009).

Perbanyakan vegetatif merupakan salah satu pilihan untuk memperoleh bibit unggul. Salah satu cara yang digunakan dalam perbanyakan vegetatif adalah dengan grafting. Perbanyakan tanaman durian dengan cara grafting sering mengalami kegagalan. Salah satu penyebab kegagalan grafting durian diduga karena pemilihan batang bawah dan batang atas yang kurang tepat. Pemilihan batang bawah berkaitan dengan pertumbuhan tanaman dimana batang bawah berada pada kondisi aktif tumbuh ketika sel-sel membelah dengan cepat. Kondisi aktif tumbuh yang cepat terjadi pada waktu tanaman masih muda. Penggunaan batang 
atas dan batang bawah berhubungan dengan kompatibilitas. Penyambungan antara batang atas dengan batang bawah yang tidak sesuai akan menghasilkan bibit dengan pertumbuhan yang lambat, selanjutnya bibit hasil sambungan akan mati. Sumber batang atas untuk dijadikan batang atas diperoleh dari berbagai jenis cabang tanaman durian yang diperkirakan masih memiliki enegi yang cukup untuk disambung. Penggunaan sumber batang atas belum spesifik bersumber dari cabang tertentu. Sumber batang atas potensial durian adalah cabang primer, sekunder, dan tersier yang memiliki keragaman kandungan makromolekul dan fitohormon. Kandungan makromolekul diperlukan sebagai penyedia energi dalam proses pembentukan kallus sedangkan fitohotmon mengontrol pertumbuhan dan perkembangan tanaman, dengan mempengaruhi pembelahan sel, perpanjangan sel dan diffferensiasi sel serta keberhasilan sambungan dan kompatibilitas.

Kendala lain yang sering dihadapi ketika melakukan penyambungan durian dengan metode sambung pucuk adalah jauhnya jarak antara pohon induk atau sumber batang atas dengan tempat atau lokasi kegiatan penyambungan, sehingga dibutuhkan waktu yang agak lama mulai dari pengambilan batang atas sampai dengan proses penyambungan. Kondisi ini menyebabkan kesegaran batang atas akan menurun karena adanya proses transpirasi dan respirasi selama penyimpanan yang selanjutnya akan menyebabkan rendahnya tingkat keberhasilan penyambungan. Selain itu jumlah batang bawah yang akan disambung sering dalam jumlah yang sangat banyak, sehingga tidak bisa dilakukan penyambungan dalam waktu sehari dan batang atas yang belum tersambung harus disimpan untuk keesokan harinya baru dilakukan penyambungan. Keragaman kandungan air, makromolekul dan auxin berbagai cabang durian akan memiliki tingkat daya simpan beragam dan akan menentukan keberhasilan penyambungan.

\section{BAHAN DAN METODE}

Percobaan dilaksanakan pada bulan Februari sampai dengan Agustus $2018 \mathrm{di}$ Kebun Percobaan Fakultas Pertanian Universitas Lakidende Unaaha Sulawesi Tenggara. Bahan yang digunakan dalam perconaan ini adalah batang atas dari berbagai sumber cabang dan disimpan sesuai dengan lama penyimpanan yaitu 0 hari, 2 hari, 4 hari dan 6 hari, dan bahan analisis meliputi amilum, dekstrin, sukrosa, laktosa, maltosa, galaktosa, fruktosa, glukosa dan arabinosa masing-masing dalam larutan $1 \%$, pereaksi Molisch, dan $\mathrm{H}_{2} \mathrm{SO}_{4}$ pekat. Alat yang digunakan dalam penelitian adalah gunting pangkas, tangga, tabung reaksi, rak tabung, dan pipet tetes, pengaduk, mortar, tabung fermentasi, kaca preparat dan papan uji.

Rancangan percobaan adakah RAK pola faktorial. Perlakuan Pertama adalah sumber batang atas yang terdiri atas 3 sumber yaitu cabang primer, cabang sekunder, dan cabang tersier. Perlakuan kedua adalah lama simpan batang atas yang terdiri atas 4 taraf waktu simpan batang atas yaitu : 0 hari, 2 hari, 4 hari dan 6 hari. Setiap unit percobaan menggunakan 10 tanaman yang diulang tiga kali sehingga secara keseluruhan terdapat 360 tanaman.

Sampel batang atas diambil dari pohon durian yang telah berumur 10 tahun. Sampel batang atas diambil pada sore hari 
sekitar pukul 15.00-18.00 dengan menggunakan gunting pangkas. Batang atas diambil pada cabang primer, cabang sekunder, dan cabang tersier. Batang atas yang diambil adalah batang atas dengan kondisi daun tua dan calon daun terakhir dalam keadaan dorman. Panjang batang atas sekitar $10 \mathrm{~cm}$ (jumlah daun 4 lembar).

Batang atas disimpan pada suhu kamar $20^{\circ} \mathrm{C}$ dengan kelembaban $75 \%$. Batang atas sebelum disimpan terlebih dahulu dibungkus dengan menggunakan kertas koran yang telah dipercikan air tetapi tidak terlalu basah, selanjutnya dibungkus lagi dengan menggunakan pelepah pisang.
Batang atas disimpan selama 6 hari, 4 hari, dan 2 hari setelah pengambilan dari pohon induk.

\section{HASIL DAN PEMBAHASAN}

\section{Jumlah Tunas}

Hasil analisis ragam menunjukkan tidak terdapat interaksi antara sumber batang atas dengan lama penyimpanan. Perlakuan mandiri lama penyimpanan berpengaruh terhadap jumlah tunas (pucuk). Hasil uji beda rata-rata pengaruh perlakuan terhadap jumlah tunas disajikan pada Tabel 1.

Tabel 1. Pengaruh sumber dan lama simpan terhadap jumlah tunas (pucuk)

\begin{tabular}{|c|c|c|c|c|c|}
\hline \multirow{2}{*}{ Sumber Batang atas } & \multicolumn{4}{|c|}{ Lama Simpan Batang atas } & \multirow{2}{*}{ Rata-Rata } \\
\hline & $\mathrm{t}_{0}$ (0 hari) & $\mathrm{t}_{1}$ (2 hari) & $t_{2}(4$ hari) & $\mathrm{t}_{4}(6$ hari $)$ & \\
\hline $\mathrm{s}_{1}$ (Cab Primer) & 2,82 & 1,58 & 1,46 & 1,43 & 1,82 \\
\hline $\mathrm{s}_{2}$ (Cab Sekunder) & 2,63 & 2,53 & 1,51 & 1,28 & 1,99 \\
\hline $\mathrm{S}_{3}$ (Cab Tersier) & 2,56 & 2,63 & 1,17 & 1,22 & 1,90 \\
\hline Rata-Rata & $2,67^{q}$ & $2,25^{p q}$ & $1,38^{p}$ & $1,31^{p}$ & \\
\hline DMRT $_{0,05}:$ & $13=0,95$ & $4=0,98$ & & & \\
\hline
\end{tabular}

Keterangan : Angka yang diikuti oleh huruf yang tidak sama pada baris $(p, q)$ berbeda nyata menurut uji DMRT 0,05

Pada Tabel 1 menunjukkan bahwa perlakuan $t_{0}$ mempengaruhi tinggi tunas lebih baik dibandingkan dengan $t_{2}$ dan $t_{3}$, tetapi tidak berbeda dengan $t_{1}$. Hasil percobaan ini menunjukkan bahwa periode penyimpanan batang atas dapat mempengaruhi jumlah tunas yang terbentuk pada penyambungan tanaman durian. Banyaknya tunas yang keluar dipengaruhi oleh kondisi cadangan makanan dan auxin yang ada pada batang atas. Selama penyimpanan terjadi perubahan kandungan karbohidrat dan kadar air, dan auxin yang terus menurun (Anita \& Susilo, 2012; Kurniastuti, 2014; Saefudin \& Wardiana, 2016).
Perlakuan berbagai sumber batang atas tidak memberikan pengaruh yang nyata terhadap jumlah tunas yang keluar Banyaknya tunas yang keluar tidak dipengaruhi oleh sumber batang atas dan lebih dipengaruhi oleh lama simpan batang atas itu sendiri. Pertumbuhan tunas pada dasarnya sangat erat hubungannya dengan waktu pecah tunas artinya semakin cepat tunas pecah maka akan semakin cepat tunas itu tumbuh asalkan unsur-unsur yang diperlukan tunas terpenuhi (Syah, 2008); (Kumar, 1996).

Penurunan jumlah tunas tidak terlepas dari kondisi senyawa karbohidrat, lemak, dan kadar air yang terus menurun selama 
penyimpanan batang tanaman, jika kandungan karbohidrat, lemak, dan kadar air mengalami peningkatan maka proses petumbuhan berupa jumlah tunas akan meningkat (Anita \& Susilo, 2012; Sukamto, 2014).

\section{Panjang Tunas (cm)}

Hasil analisis ragam menunjukkan bahwa pengaruh perlakuan sumber dan lama simpan serta interaksinya tidak berpengaruh nyata terhadap panjang tunas. Hasil pengamatan pengaruh sumber dan lama simpan terhadap panjang tunas disajikan pada Gambar 1.

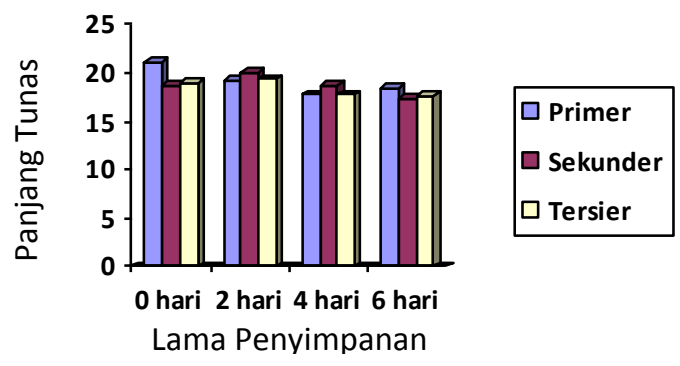

Gambar 1. Hasil pengamatan pengaruh sumber dan lama simpan terhadap panjang tunas

Gambar 1 menunjukkan bahwa lama penyimpanan 0 hari $\left(t_{0}\right)$ panjang tunas tertinggi pada cabang primer $\left(s_{1}\right)$, pada lama penyimpanan 2 hari $\left(t_{1}\right)$ panjang tunas tertinggi terjadi pada cabang sekunder $\left(s_{2}\right)$, pada lama penyimpanan 4 hari $\left(t_{2}\right)$ panjang tunas tertinggi terjadi pada cabang sekunder $\left(s_{2}\right)$, dan pada lama penyimpanan 6 hari $\left(t_{3}\right)$ panjang tunas tertinggi terjadi pada cabang primer $\left(\mathrm{s}_{1}\right)$.

Hasil penelitian pada Gambar 1 menjelaskan bahwa makin lama batang atas disimpan akan menghasilkan tunas yang pendek. Hal ini mungkin karena selama penyimpanan terjadi penguapan dan proses fisiologis lainnya yang menyebabkan batang atas kurang segar dan kehilangan sebagian energinya, sehingga pertumbuhan tunas terhambat. Batang atas yang langsung disambung pertumbuhannya lebih baik jika dibandingkan dengan batang atas yang disimpan (Syah, 2008; Kurniastuti, 2014).

Pelambatan panjang tunas terjadi pada cabang primer, diikuti pada cabang tersier dan cabang sekunder. Pelambatan jumlah tunas tidak terlepas dari kondisi senyawa karbohidrat, lemak, dan kadar air yang terus menurun selama penyimpanan batang tanaman, jika kandungan karbohidrat, lemak, dan kadar air mengalami peningkatan maka proses petumbuhan berupa jumlah tunas akan meningkat (Sari \& Susilo, 2012; Sukamto et al., 2014). Selain itu kandungan auxin yang cukup tinggi pada cabang primer. Kondisi ini tentu akan berdampak pada proses perpanjangan tunas. Proses perpanjangan tunas membutuhkan karbohidrat, Lemak, kadar air, dan auxin yang cukup. Penurunan kadar karbohidrat, lemak, kadar air, dan auxin akan menghambat pembelahan dan pembesaran sel. Jumlah dan ukuran sel yang terhambat akan mengakibatkan perpanjangan tunas melambat atau dapat terhenti (Kurniastuti 2014; Larekeng et al., 2014)

\section{Jumlah Daun (helai)}

Hasil analisis ragam menunjukkan bahwa pengaruh interaksi perlakuan sumber batang atas dan lama simpan batang atas terhadap jumlah daun tidak berpengaruh nyata, hanya lama simpan yang berpengaruh nyata terhadap jumlah daun. Hasil uji beda rata-rata pengaruh perlakuan terhadap jumlah tunas disajikan pada Tabel 2. 
Tabel 2. Pengaruh sumber dan lama simpan terhadap jumlah daun (helai)

\begin{tabular}{|c|c|c|c|c|c|}
\hline \multirow{2}{*}{$\begin{array}{c}\text { Sumber Batang } \\
\text { atas }\end{array}$} & \multicolumn{4}{|c|}{ Lama Simpan Batang atas } & \multirow{2}{*}{ Rata-Rata } \\
\hline & $t_{0}$ (0 hari) & $\mathrm{t}_{1}(2$ hari $)$ & $t_{2}(4$ hari $)$ & $t_{3}$ (6 hari) & \\
\hline $\mathrm{s}_{1}$ (Cab Primer) & 5,55 & 4,71 & 3,67 & 2,00 & 3,98 \\
\hline $\mathrm{s}_{2}$ (Cab Sekunder) & 4,47 & 5,50 & 3,53 & 2,00 & 3,88 \\
\hline $\mathrm{s}_{3}$ (Cab Tersier) & 5,36 & 4,64 & 3,33 & 2,56 & 3,97 \\
\hline Rata-Rata & $5,13^{9}$ & $4,95^{9}$ & $3,51^{p q}$ & $2,19^{p}$ & \\
\hline DMRT $_{0,05}$ : & $2=1,88 \quad 3$ & $4=2,0$ & & & \\
\hline
\end{tabular}

Keterangan: Angka yang diikuti oleh huruf yang tidak sama pada baris (rata-rata huruf $p, q$ ) berbeda nyata menurut uji DMRT 0,05

Pada Tabel 2 menunjukkan bahwa Jumlah daun tertinggi dipengaruhi oleh perlakuan $t_{0}$, dan $t_{1}$, yang tidak berbeda nyata dengan perlakuan $t_{3}$, sedangkan perlakuan $t_{4}$ mempengaruhi jumlah daun terendah. Jumlah daun yang terbentuk mengalami penurunan selama penyimpanan. Hal ini terkait dengan jumlah kabohidrat yang terus berkurang sejalan dengan lama penyimpanan. Pertumbuhan daun terjadi akibat pembelahan, pemanjangan dan diferensiasi sel-sel, pada kondisi ini diperlukan karbohidrat (Kurniastuti, 2014); (Rahardjo \& Djauhariya, 2009);

\section{Diameter Batang $(\mathrm{cm})$}

Hasil analisis ragam menunjukkan bahwa pengaruh perlakuan sumber batang atas dan lama simpan batang atas tidak memberikan pengaruh interaksi yang nyata terhadap diameter batang, sedangkan pengaruh mandiri keduanya bepegaruh nyata terhadap diameter batang $(\mathrm{cm})$ seperti disajikan pada Tabel 3.

Tabel 3. Pengaruh sumber dan lama simpan terhadap diameter batang $(\mathrm{cm})$

\begin{tabular}{|c|c|c|c|c|c|}
\hline \multirow{2}{*}{ Sumber Batang atas } & \multicolumn{4}{|c|}{ Lama Simpan Batang atas } & \multirow{2}{*}{ Rata-Rata } \\
\hline & $\mathrm{t}_{0}(0$ hari $)$ & $\mathrm{t}_{1}$ (2 hari) & $\mathrm{t}_{2}$ (4 hari) & $t_{3}$ (6 hari) & \\
\hline $\mathrm{s}_{1}$ (Cab Primer) & 1,50 & 1,20 & 1,20 & 1,17 & $1,27^{b}$ \\
\hline $\mathrm{s}_{2}$ (Cab Sekunder) & 1,33 & 1,20 & 1,23 & 1,23 & $1,25^{b}$ \\
\hline $\mathrm{s}_{3}$ (Cab Tersier) & 1,20 & 1,17 & 1,00 & 1,00 & $1,09^{a}$ \\
\hline Rata-Rata & $1,34^{q}$ & $1,19^{p}$ & $1,14^{p}$ & $1,13^{p}$ & \\
\hline DMRT $0,05:^{0}$ & $15 \quad 3=0,15$ & $4=0,16$ & & & \\
\hline
\end{tabular}

Keterangan : Angka yang diikuti oleh huruf yang tidak sama pada baris (rata-rata huruf a,b) dan kolom (rata-rata huruf $p, q$ ) yang tidak sama berbeda nyata menurut uji $\mathrm{DMRT}_{0,05}$

Pada Tabel 3 menunjukkan bahwa perlakuan sumber batang atas tertinggi adalah perlakuan sumber batang atas dari cabang primer dan cabang sekunder berbeda nyata dengan perlakuan sumber batang atas cabang tersier. Hal ini diduga kandungan karbohidrat dan air masih cukup untuk mendukung pertumbuhan diameter bibit hasil sambung samping tanaman durian. Perlakuan sumber batang 
atas dan perlakuan lama simpan batang atas berpengaruh nyata terhadap diameter batang bibit hasil sambung samping tanaman durian.

Perlakuan sumber batang atas tertinggi adalah perlakuan sumber batang atas dari cabang primer dan cabang sekunder berbeda nyata dengan perlakuan sumber batang atas cabang tersier. sedangkan perlakuan lama simpan batang atas tertinggi adalah tanpa penyimpanan batang atas berbeda nyata dengan perlakuan lama simpan batang atas 2, 4, dan 6 hari. Perkembangan diameter tunas mencerminkan perbedaan tingkat ketuaan jaringan batang bahan stek. Semakin besar diameter semakin lanjut perkembangan jaringan stek tersebut atau semakin kecil diameter semakin muda jaringan. Bervariasinya tingkat akumulasi karbohidrat dan bahan cadangan makanan lainnya dari masing-masing setek yang berbeda ukuran diameter tersebut. Diameter batang juga merupakan pertumbuhan sekunder, pertumbuhan diameter batang terjadi akibat pembelahan sel-sel kambium ke dalam membentuk xilem dan ke luar membentuk floem. Bila kambium membelah dengan aktif, pembentukan sel-sel berjalan dengan cepat sekali sehingga pertumbuhan diameter batang juga lebih cepat. Lebih besarnya diameter tanaman asal grafting dari batang atas primer disebabkan oleh pembelahan kambium yang lebih cepat dibandingkan tanaman grafting dari batang atas sekunder atau tersier (Sudjijo, 2009; Suharsi, 2013; Tanveer et al., 2016; Rahman, 2017).

\section{Luas Daun Total $\left(\mathrm{cm}^{2}\right)$}

Hasil analisis ragam menunjukkan bahwa pengaruh perlakuan sumber dan lama simpan berpengaruh nyata sedangkan interaksinya tidak berpengaruh nyata terhadap luas daun total tanaman. Hasil uji beda rata-rata pengaruh perlakuan terhadap luas daun total disajikan pada Tabel 4.

Tabel 4. Pengaruh sumber dan lama simpan terhadap luas daun total $\left(\mathrm{cm}^{2}\right)$

\begin{tabular}{|c|c|c|c|c|c|}
\hline \multirow{2}{*}{$\begin{array}{l}\text { Sumber } \\
\text { atas }\end{array}$} & \multicolumn{4}{|c|}{ Lama Simpan Batang atas } & \multirow{2}{*}{ Rata-Rata } \\
\hline & $t_{0}$ (0 hari) & $\mathrm{t}_{1}(2$ hari $)$ & $\mathrm{t}_{2}$ (4 hari) & $t_{3}$ (6 hari) & \\
\hline $\mathrm{s}_{1}$ (Cab Primer) & 61,04 & 47,07 & 47,39 & 29,50 & $46,25^{b}$ \\
\hline $\mathrm{s}_{2}$ (Cab Sekunder) & 50,63 & 44,48 & 39,12 & 29,25 & $40,87^{a b}$ \\
\hline $\mathrm{s}_{3}$ (Cab Tersier) & 45,95 & 32,11 & 32,65 & 27,50 & $34,55^{a}$ \\
\hline Rata-Rata & $52,54^{r}$ & $41,22^{q}$ & $39,72^{q}$ & $28,75^{p}$ & \\
\hline DMRT $_{0,05}:$ & $2=9,11$ & \multicolumn{2}{|c|}{$3=9,58 \quad 4=9,86$} & & \\
\hline
\end{tabular}

Tabel 4 menunjukkan luas daun tertinggi dipengaruhi oleh lama penyimpanan 0 hari dibandingkan dengan perlakuan lainnya. Cabang primer mempengaruhi luas daun total tertinggi apabila dibandingkan dengan cabang tersier. Hasil percobaan pada Tabel 4 bahwa kandungan karbohidrat yang sangat inggi dibutuhkan untuk pertumbuhan daun terutama pembelahan, pemanjangan dan 
diferensiasi sel-sel pada meristem dari kuncup terminal dan kuncup lateral yang memproduksi sel-sel baru secara periodik, sehinggga akan membentuk daun baru. Terbentuknya daun baru akan meningkatkan laju fotosintesis (Nasaruddin, 2010). Secara mandiri perlakuan lama simpan batang atas terhadap luas daun total tertinggi adalah berasal dari perlakuan tanpa penyimpanan dan berbeda nyata dengan perlakuan lainnya. Hal ini berkaitan dengan kandungan auxin yang berbeda akibat penyimpanan batang atas. Hormon auxin juga ikut berperan dalam hal pertambahan laus daun. Auxin banyak digunakan dalam kerja mikropropagasi dan bekerjasama dengan nutrien untuk memelihara pertumbuhan organ seperti daun (Tanveer et al., 2016). Hal ini disebabkan kaena karbohidrat, lemak, dan kadar air yang terus menurun selama penyimpanan batang tanaman, jika kandungan karbohidrat, lemak, dan kadar air mengalami peningkatan maka proses pertumbuhan luas daun akan meningkat (Tidi et al., 2012; Saefudin \& Wardiana, 2016).

\section{SIMPULAN}

Berdasarkan hasil penelitian yang telah dilakukan dapat disimpulkan bahwa:

1. Interaksi sumber batang atas dan lama penyimpanan batang atas tidak mempengaruhi jumlah tunas, panjang tunas, diameter tunas dan luas daun total tanaman durian.

2. Sumber batang atas cabang primer menghasilkan diameter batang dan luas daun terbesar.

3. Cabang atas yang tidak mengalami penyimpanan memperlihatkan luas daun, diamater batang, jumlah daun, dan jumlah tunas tertinggi.

\section{UCAPAN TERIMA KASIH}

Terima Kasih kami ucapkan sebesarbesarnya kepada Pimpinan Universitas Lakidende, Fakultas Pertanian Universitas Lakidende, dan Dosen di lingkungan Program Studi Ilmu Pertanian yang telah memberikan dukungan dana maupun dorongan moril sehingga penelitian ini dapat terlaksana dengan baik. Secara Khusus kami ucapkan kepada Murdiyoko, SP sebagai tenaga lapangan dan enomerator data

\section{DAFTAR PUSTAKA}

Adelina, E, Y. Tambing \& M. S. Saleh. (2009). Potensi pengembangan perbanyakan vegetatif durian. In Hasil-Hasil Penelitian Dan Pengembangan Di Sulawesi Tengah, 122-`129.

Anita, Sari I., \& Agung Wahyu Susilo. (2012). Keberhasilan sambungan pada beberapa jenis batang atas dan famili batang bawah kakao. Pelita Perkebunan 28 (2): 326-31.

Ciobotari, Gheorghii, Maria Brinza, Aliona Morariu, \& Gica Gradinariu. (2010). Graft incompatibility influence on assimilating pigments and soluble sugars amount of some pear (Pyrus sativa) cultivars. Notulae Botanicae Horti AgrobotaniciCluj-Napoca 38 (1): 187-92.

Firman, C \& Ruskandi. (2009). Teknik pelaksanaan percobaan pengaruh naungan terhadap keberhasilan penyambungan tanaman jambu 
mete." Buletin Teknik Pertanian 14 (1): 27-30.

Kumar, G.N.M. (1996). Propagation of plants by grafting and budding. Pacific North West Extension Publication.

Kurniastuti. (2014). Pengaruh defoliasi daun batang atas dan lama tunda sambung pada keberhasilan penyambungan bibit. Grafting 4 (1).

Larekeng, Yuldanto, Sakka Samudin, \& Hendry Barus. (2014). Kajian berbagai lama penyimpanan batang atas terhadap hasil sambung samping kakao klon Sulawesi. Mitra Sains 5 (1): 89-97.

Nasaruddin. (2010). Dasar-Dasar Fisiologi Tumbuhan.

Rahardjo, M., \& E. Djauhariya. (2009). Pengaruh umur batang bawah dan lama penyimpanan batang atas terhadap keberhasilan grafting tanaman mengkudu. In Prosiding Seminar Nasional Tumbuh Obat Indonesia, 87-95.

Rahman, Murad Aftab, Mohammad Abdul Rauf. (2017). Comparative study on compatibility and growth response of pear varieties on different rootstocks at Nursery. Pure Appl. Biol 6 (1): 28692.

Saefudin, Saefudin, \& Edi Wardiana. (2016). Pengaruh penyimpanan dan pengemasan batang entres terhadap keberhasilan okulasi hijau tanaman karet. Jurnal Tanaman Industri Dan Penyegar 3 (2): 95. https://doi.org/10.21082/jtidp.v3n2.2 016.p95-102.

Sudjijo. (2009). Pengaruh ukuran batang bawah dan batang atas Terhadap pertumbuhan durian monthong, hepe, dan DCK-01. Jurnal Hortikultura
19 (1): 89-94.

Suharjo, Andi Bahrun \& La Ode Safuan. (2017). Effect of source and storage times of scion to carbohydrate, protein, lipids, and auxin content at durian nursery (Durio Zibethinus. Murr)." International Journal of Recent Advances in Multidisciplinary Research 04 (09): 2819-24.

Suharsi. (2013). Pertumbuhan mata tunas jeruk keprok hasil okulasi pada berbagai media tanam dan umur batang bawah. IImu Pertanian Indonesia (JIPI) 18 (2): 97-100.

Sukamto, L Agus, Reni Lestari P \& Winda U. (2014). Tingkat hidup dan pertumbuhan avokad hasil sambung pucuk batang atas yang disimpan dalam pelepah batang pisang. Buletin Kebun Raya 17 (1).

Syah, Jamal M Anwaruddin. (2008). Pengaruh lama penyimpanan entris terhadap keberhasilan sambung pucuk beberapa varietas avokad. Jurnal Hortikultura 18 (4): 402-8.

Syah, M Anwarudin, $\mathrm{R}$ Poerwanto, $\mathrm{T}$ Purnama, F Usman \& I Muas. (2009). Pengaruh posisi sayatan dan penyisipan entris pada batang bawah terhadap keberhasilan Penyambungan dan kecepatan pertumbuhan benih manggis. Jurnal Hortikultura 17 (4): 328-34.

https://doi.org/10.21082/jhort.v17n4 .2007.p.

Tanveer, Shah Syed, Shahid Rahman \& Nadeem Khan. (2016). Viability of meyer lemon over sour orange rootstock. Pure Appl. Biol 5 (2): 32631.

Tidi, Dhalika, Mansyur \& Atun Budiman. (2012). Evaluasi karbohidrat dan lemak batang tanaman pisang hasil 
fermentasi an aerob dengan suplementasi nitrogen dan sulfur sebagai bahan pakan ternak. Pastura 2 (2): 97-101.

Vural, Ugur, Hatice Dumanoglu \& Veli Erdogan. (2009). Effect of grafting / budding techniques and time on propagation of black mulberry (Morus Nigra I.) in Cold Temperate Zones." Propagation of Ornamental Plants 8 (2): 55-58.

Yang, Yingzhen, Mao Linyong, Yingyos Jittayasothor, Youngmin Kang, Chen Jiao, Zhangjun Fei, and Gan-Yuan Zhong. (2015). Messenger RNA exchange between scions and rootstocks in grafted grapevines." BMC Plant Biology 15: 251-54. 